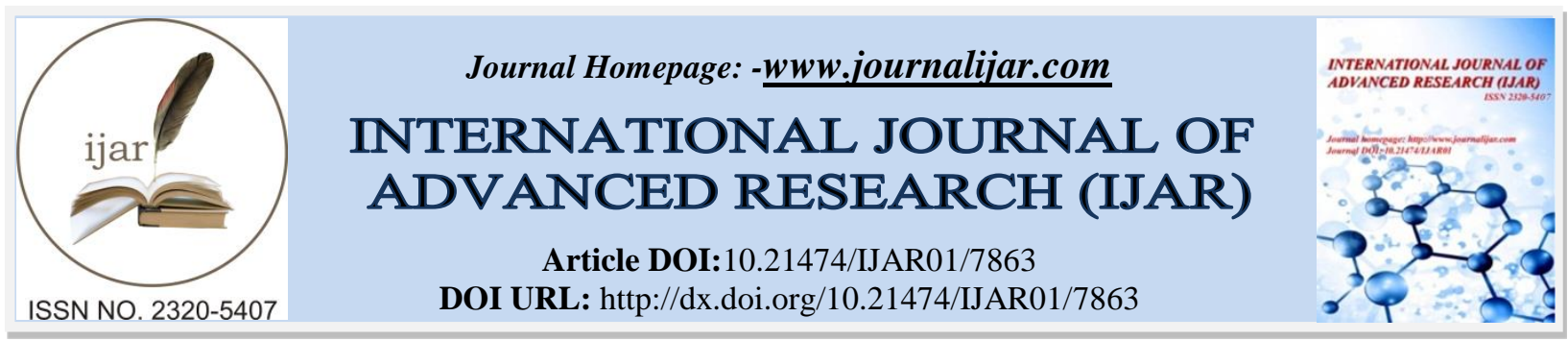

RESEARCH ARTICLE

\title{
STUDY OF THE PERFORMANCE OF FOUR STRAINS OF SACCHAROMYCES CEREVISIAE DURING ETHANOL PRODUCTION WITH CASHEW APPLE JUICE (ANACARDIUM OCCIDENTALE L.).
}

\section{Hêdiblè Gbêgninou Luc ${ }^{1}$, Adjou Sènan Euloge ${ }^{1}$, Agbangnan-Dossa Cokou Pascal ${ }^{2}$ and Soumanou Mohamed Mansourou'.}

Unité de Recherche en Génie Enzymatique et Alimentaire (URGEA)/ Laboratoire d'Etude et de Recherche en Chimie Appliquée (LERCA)/ Ecole Polytechnique d'Abomey-Calavi (EPAC)/ Université d'Abomey-Calavi (UAC), 01 BP 2009, Cotonou, Bénin.

Unité de Recherche sur les Interactions Moléculaires (URIM)/ Laboratoire d'Etude et de Recherche en Chimie Appliquée (LERCA)/ Ecole Polytechnique d'Abomey-Calavi (EPAC)/ Universitéd'Abomey-Calavi (UAC), 01 BP 2009, Cotonou, Bénin.

\section{Manuscript Info}

Manuscript History

Received: 10 August 2018

Final Accepted: 12 September 2018

Published: October 2018

Keywords:

Cashew apple juice, Saccharomyces cerevisiae, fermentation, ethanol.

\section{Abstract}

Cashew nut production is booming in Benin and picking apples are a valuable commodity with a high nutrient content. The main objective of this study is the valorization of cashew apples through the study of the performance of four strains of Saccharomyces cerevisiae during ethanol production from cashew apple juice. The alcoholic fermentation of cashew apple juice with an initial concentration of $157.5 \mathrm{~g} / \mathrm{L}$ of reducing sugars and $1 \mathrm{~g} / \mathrm{L}$ of yeast was conducted anaerobically at room temperature $\left(30.8{ }^{\circ} \mathrm{C}\right)$ at $\mathrm{pH} 3.85-4.25$ for 96 hours in polyethylenic triplicate bioreactors. During fermentation, it has been tested the performance of strains such as Saccharomyces cerevisiae var. bayanus, Saccharomyces cerevisiae Safale K-97, Saccharomyces cerevisiae Saflager W-34/70 and baker's yeast. After 48 hours of fermentation the maximum concentration of ethanol $(104.3 \mathrm{~g} / \mathrm{L})$ is recorded with the yeast Saccharomyces cerevisiae var. bayanus with a residual sugar of $1.25 \mathrm{~g} / \mathrm{L}$. It is followed by Safale K-97, Saflager W-34/70 and baker's yeast, which have ethanol concentrations of $93.69 ; 73.95 ; 58.16 \mathrm{~g} / \mathrm{L}$ respectively. In addition, the yeast Saccharomyces cerevisiae var. bayanus showed the highest efficiency $(96.025 \%)$, the highest productivity $\left(1.604 \mathrm{~g} . \mathrm{L}^{-1} \cdot \mathrm{h}^{-1}\right)$, the highest ethanol yield $\left(0.491{\mathrm{~g} . \mathrm{g}^{-1}}^{-1}\right)$ and the highest rate substrate consumption $\left(2.067 \% . \mathrm{h}^{-1}\right)$.

It appears from this study that the yeast Saccharomyces cerevisiae var. bayanus has the best bioconversion performance of fermentable sugars in ethanol. Therefore, it can be used as an effective strain in the perspective of intensive ethanol production.

Copy Right, IJAR, 2018,. All rights reserved.

Corresponding Author: Soumanou Mohamed Mansourou.

Address: Unité de Recherche en Génie Enzymatique et Alimentaire (URGEA)/ Laboratoire d'Etude et de Recherche en Chimie Appliquée (LERCA)/ Ecole Polytechnique d'Abomey-Calavi (EPAC)/ Université d'Abomey-Calavi (UAC), 01 BP 2009, Cotonou, Bénin. |Email: msoumanoufr@yahoo.fr/ mohamed.soumanou@epac.uac.bj/ Tél: (+229) 97877870. 


\section{Introduction}

The decline in dependence on fossil fuels following its exhaustion, the increase in the global price of fuel, the increase in the population and the increase in global warming have increased in recent decades the interest of the use renewable raw materials to produce ethanol (Yu et Zhang, 2004, Demirbas et al., 2007, Demirbas, 2008). Ethanol is of undeniable economic importance because it is used in various sectors of industrial activities including the agri-food sector for the production of alcoholic beverages such as alcohol at $40^{\circ} \mathrm{GL}$, wine, beer, cider, vodka and gin, whiskey, brandy (Kaidi et Touzi, 2001). It is also used in the manufacture of solvents, detergents, disinfectants and chemical intermediates. Ethanol is also used in combination with gasoline to produce gaseous alcohol to fuel automobiles (Yu et Zhang 2004, Demirbas et al., 2007; Demirbas, 2008). It is a clean source of burning, renewable energy (Reddy et $a l$., 2007). It is also an important raw material in the synthesis of aldehydes, ketones, carboxylic acid, carboxylic acid derivatives and hydroxyl groups which are important components of many pharmaceutical drugs (Solomon et al., 2008). The bestknown and most widely used means of producing ethanol is chemical production from petroleum products (Boulal et al., 2013). This process of producing ethanol is increasingly rejected because of the high cost of oil and its impact on the ecosystem. In Benin, ethanol is frequently used in various fields such as the food industry, the pharmaceutical industry, the cosmetics industry, in research laboratories and during traditional cults and festive ceremonies. The main raw material used for its production is palm wine, obtained most often by slaughtering and/or daily cutting of the apical bud (Kouchade et $a l ., 2017$ ). This practice is not only lethal for palms but also contributes to the destruction of the plant cover. Thus, it is imperative to diversify the sources of ethanol production, including the choice of cashew apple, a widely available agroresource. Cashew (Anacardium occidentale L.) is a tree native to South America (Olher 1967). Interest in this tree is focused on cashews which are the object of an international trade and which gives notoriety to the cashew nut (Lacroix, 2003). In 2015, the sub-region is ranked as the world's leading production area with more than 1,350,000 tonnes of raw nuts in front of Asia (India, Vietnam, Cambodia, Indonesia) which remains around 1,300,000 tonnes (Etéka, 2017). In Benin, cashew nuts are the second most important export crop after cotton (Yabi et al., 2018). In 2017, Benin's exports of cashew nuts are estimated at about 132000 tonnes (Akomagni, 2017). In 2016, Benin is ranked sixth in the world with a production of 125,728 tonnes after Viet Nam, Nigeria, India, Côte d'Ivoire and Philippine (FAO, 2018). Unlike nuts, which are of great interest, the economic exploitation of the cashew apple remains underdeveloped and unreasonable. However, several studies have shown the richness of the cashew apple. It contains minerals, vitamin C, polyphenols and proteins (Adou et al., 2011, Adou et al., 2012a, Adou et $a$., 2012b, Kubo et al., 2006, Cavarlho et al., 2006). which give it antioxidant properties and make it an effective remedy for chronic dysentery in Cuba and Brazil (Kubo et al., 2006; Carvarlho et al., 2006). In India and Brazil, cashew apples are processed for the production of fruit juices or liqueurs (Cavalcante et al., 2003, Nanjundaswamy et al., 2001). According to Bando et Silva (2001), fruit growing is an alternative to the development and recovery of local economies. In addition, the anti-poverty strategy emphasizes the processing of our raw materials (Adou et $a$ l., $2012 \mathrm{~b}$ ). According to Holanda et al. (1998), the quantity of cashew apples abandoned each year represents a raw material potential that could be valorized by anaerobic bioconversion of glucose, fructose or sucrose into ethanol by the yeast Saccharomyces cerevisiae (Reddy et al., 2007). The valorization of these apples would be an important stake, not only in the field of forestry and the protection of the environment (reforestation, soil restoration, conservation of the land heritage in the cotton zone, etc.), but also on the socio-economic level (job creation, income-generating activities, socio-economic integration of women, improvement of the balance of payments, etc.) (Tokpa and Adoho,2006).

It is in this context that the present study was initiated. Its main objective is the food valorization of cashew apples (Anacardium occidentale L.) through the study of the performance of four strains of Saccharomyces cerevisiae during the production of ethanol from cashew apple juice (Anacardium occidentale L.).

\section{Material and Methods \\ Vegetable material}

The raw material used consisted of cashew apples collected in central Benin in the commune of Bantè $\left(8^{\circ} 25^{\prime} 0^{\prime}\right.$ ' $\mathrm{N}$ and $\left.1^{\circ} 52^{\prime} 60^{\prime \prime} \mathrm{E}\right)$. Interest in this commune is that it corresponds to the best cashew-producing region in Benin (Dédéou et $a l ., 2015$, Gbohaïda et $a l ., 2015$ ) and enjoys an interesting geographic position (Tandjiékpon et al. 2005).

\section{Preparation of cashew apple juice}

Once transported to the laboratory, the cashew apples were removed from their nuts and washed. The apples are washed by immersion in chlorinated water $(50 \mathrm{ppm})$ for 15 minutes. Then, they were selected and washed with distilled water. Then, sliced and crushed using a blender (Blender LB20E, Torrington, USA, 2002). The resulting cashew apple puree was filtered using a filter of different mesh respectively 400; 300; 200; 150 and 50 micrometers. 
The juice samples were sterilized by wet steam autoclaving at $110{ }^{\circ} \mathrm{C}$ for $10 \mathrm{~min}$. The processed juice samples contain $157.5 \mathrm{~g} / \mathrm{L}$ of reducing sugars (glucose + fructose) used in all experiments.

\section{Microorganisms and culture conditions}

\section{Ferments}

Four active dry yeast strains are used as organic ferments. The total description of the strains tested is made in the table below:

Table 1: Microorganisms used during alcoholic fermentation

\begin{tabular}{|c|c|c|c|c|c|c|}
\hline \multirow{2}{*}{ Genus } & \multirow{2}{*}{ Species } & \multirow{2}{*}{ Variety } & \multicolumn{2}{|c|}{ Nomenclature } & \multirow[t]{2}{*}{ Origin } & \multirow[t]{2}{*}{ Characteristics } \\
\hline & & & Usual & adopted & & \\
\hline Saccharomyces & cerevisiae & cerevisiae & $\begin{array}{l}\text { Bakery } \\
\text { yeast }\end{array}$ & $S_{1}$ & $\begin{array}{c}\text { JOCK S.A. } \\
\text { company located in } \\
\text { Bordeaux, France }\end{array}$ & $\begin{array}{l}\text { Used in breadmaking } \\
\text { and available in } \\
\text { supermarkets } \\
\text { Benin }\end{array}$ \\
\hline Saccharomyces & cerevisiae & Bayanus & $\begin{array}{l}\text { Bioferm } \\
\text { Killer }\end{array}$ & $\mathrm{S}_{2}$ & $\begin{array}{c}\text { Brouwland } \\
\text { industrial company } \\
\text { located in Beverlo, } \\
\text { Belgium }\end{array}$ & $\begin{array}{l}\text { Used in oenology and } \\
\text { has a very high } \\
\text { resistance to alcohol } \\
\text { up to } 16 \% \text { vol and } \\
\text { contains the factor" } \\
\text { Killer" }\end{array}$ \\
\hline Saccharomyces & cerevisiae & cerevisiae & $\begin{array}{l}\text { Safale K- } \\
\quad 97\end{array}$ & $\mathrm{~S}_{3}$ & $\begin{array}{l}\text { Lesaffre industrial } \\
\text { company located }\end{array}$ & $\begin{array}{l}\text { High fermentation } \\
\text { yeast adapted to the } \\
\text { brewing of fine } \\
\text { Belgian white beers }\end{array}$ \\
\hline Saccharomyces & cerevisiae & cerevisiae & $\begin{array}{l}\text { Saflager } \\
\text { W-34/70 }\end{array}$ & $\mathrm{S}_{4}$ & & $\begin{array}{l}\text { Used in the brewing } \\
\text { industry }\end{array}$ \\
\hline
\end{tabular}

\section{Pre-culture medium}

The pre-culture medium is a nutritious broth (buffered peptone water) composed of: Peptone $(10,0 \mathrm{~g} / \mathrm{L})$; Sodium chloride $(5.0 \mathrm{~g} / \mathrm{L})$; Disodium hydrogen phosphate $(3.5 \mathrm{~g} / \mathrm{L})$; Potassium hydrogen phosphate $(1.5 \mathrm{~g} / \mathrm{L})$; Final pH: 7.2 \pm 0.2 .

\section{Preparation of the inoculum}

A mass of $1 \mathrm{~g}$ of each yeast strain is introduced into $10 \mathrm{~mL}$ of nutrient broth (buffered peptone water). The mixture thus obtained is rapidly homogenized aerobically and then allowed to stand at $25{ }^{\circ} \mathrm{C}$ for 30 minutes. Then it is incubated at room temperature $\left(30-32{ }^{\circ} \mathrm{C}\right)$ with rotary stirring for about half an hour in order to facilitate the revivification of yeast cells, necessary for a good fermentative activity.

\section{Pre-fermentation}

It allows the acclimatization of yeast cells to the substrate to be fermented. It was carried out by first mixing the inoculum with a volume corresponding to $10 \%(\mathrm{v} / \mathrm{v})$ of the total volume of the substrate to be fermented, equal to $100 \mathrm{~mL}$ of the must. The mixture is introduced into a fermenter and then incubated aerobically for 24 hours at room temperature $\left(30-32{ }^{\circ} \mathrm{C}\right)$ on a TE 240 rotary shaker at $150 \mathrm{rpm}$. The fermenter used are sterile bottles with identical caps.

\section{Fermentation}

The remaining $90 \%$ wort is added to each sample from the pre-fermentation. The total volume of the mixture in each bioreactor is then about $1000 \mathrm{~mL}$. After rotary shaking, the study of the performance of four Saccharomyces cerevisiae strains was evaluated in the production of ethanol from cashew apple juice (Anacardium occidentale L.). Batchcontrolled batch fermentation under anaerobic conditions was applied at laboratory temperature of $30.8{ }^{\circ} \mathrm{C}$ for 96 hours. The fermentation is conducted in 15 polyethylene bioreactors of capacity $3 \mathrm{~L}$ and distributed in triplicate. The 
control was carried out without the addition of selected yeast. To follow the evolution of the fermentation, Samples were taken every 24 hours and subjected immediately to physicochemical and biochemical analyzes.

\section{Analytical methods}

\section{Cell biomass}

Cell biomass was determined by adopting the dry mass method described by Parente et al. (2014). It consists of separating the cells from the medium, drying them and then weighing them.

\section{Concentration of reducing sugars}

The concentration of reducing sugars was determined by the colorimetric method with dinitrosalicylic acid (DNS) described by de Sousa et al. (2010).

\section{pH and total titratable acidity}

The $\mathrm{pH}$ and titratable acidity of the must was determined using the methods described by Adou et $a l$. (2012b) and Massengo et al. (2014) respectively.

\section{Ethanol concentration}

The ethanol concentration was determined using an Assistent vinometer (4200, Germany) graduated from 0 to $25 \%$ (v/v). The values obtained were converted to $\mathrm{g} / \mathrm{L}$ using the method described by Parente et al. (2014).

\section{Refractometric solids content}

The content of refractometric dry extract was determined using a portable refractometer by the method of Soyer et $a l$. (2003).

\section{Protein content}

The protein content was determined by the method described by Gornall et al. (1949).

\section{Efficiency and Total hourly productivity}

Efficiency, also known as the yield of alcoholic fermentation, gives quantitative values of the efficiency with which yeast converts reducing sugars into ethanol. Efficiency $(\eta ; \%)$ and total hourly productivity $\left(\mu_{\mathrm{P}} ; \mathrm{g} \cdot \mathrm{L}^{-1} \cdot \mathrm{h}^{-1}\right)$ were determined according to the methods of Silva (2006) and Parente et al. (2014) respectively.

\section{Ethanol yield and substrate conversion factor to cell biomass}

The ethanol yield (Yp/s ; g. $\left.\mathrm{g}^{-1}\right)$ and the substrate conversion factor to cell biomass (Yx/s ; g. $\left.\mathrm{g}^{-1}\right)$ were determined by the method described by Parente et al. (2014).

\section{Limit attenuation and specific rate of sugar consumption}

The limiting attenuation $(\mathrm{Al} ; \%)$ and the specific rate of consumption of sugars $\left(\mu_{S} ; \% \cdot \mathrm{h}^{-1}\right)$ were calculated from equations 1 and 2:

$$
\begin{gathered}
A l(\%)=\frac{(S o-S r)}{S o} \times 100 \\
\mu_{s}=\frac{\frac{(S o-S r)}{S o} \times 100}{t}
\end{gathered}
$$

$\mathbf{S}_{\mathbf{0}}$ : Initial concentration of reducing sugars $(\mathrm{g} / \mathrm{L})$

$\mathbf{S}_{\mathbf{r}}$ : Concentration of residual reducing sugars $(\mathrm{g} / \mathrm{L})$

t: Fermentation time (h)

\section{Specific rate of cell growth}

The specific rate of cell growth $\left(\mu_{\mathrm{x}} ; \mathrm{h}^{-1}\right)$ was determined using the method described by Stroppa et al. (2009) 


\section{Statistical analysis}

The data was processed using Microsoft Excel 2007 and SPSS 16.0 software. The comparison of averages was made with the Turkey test with a significance level $\mathrm{P}<0.05$.

\section{Results and Discussion}

Evolution of the concentration of reducing sugars and ethanol as a function of the duration of fermentation according to the four strains of Saccharomyces cerevisiae

The analysis of Figure 1 shows that the kinetics of alcoholic fermentation takes place in three phases. The first phase is from the $1^{\text {st }}$ to the $2^{\text {nd }}$ day and corresponds to a sudden decrease of the reducing sugars by the strains $\mathrm{S} 1, \mathrm{~S} 2, \mathrm{~S} 3, \mathrm{~S} 4$ and the wild strains in each reaction medium. Indeed, the concentration of reducing sugars goes from $157.5 \mathrm{~g} / \mathrm{L}$ to $39.46 ; 1.25 ; 12.39 ; 16.7 ; 32.3 \mathrm{~g} / \mathrm{L}$, a decrease of $118.04 ; 156.25 ; 145.11 ; 140.8 ; 127.2 \mathrm{~g} / \mathrm{L}$ respectively for yeasts $\mathrm{S} 1$, S2, S3, S4 and wild-type strains. It follows from the above that yeast S2 has the highest consumption of reducing sugars $(156.25 \mathrm{~g} / \mathrm{L})$ followed by yeasts S2 $(145.11 \mathrm{~g} / \mathrm{L}) ; \mathrm{S} 3(140.8 \mathrm{~g} / \mathrm{L})$ and wild strains $(127.2 \mathrm{~g} / \mathrm{L})$. Yeast S1 has the lowest consumption of reducing sugars $(118.04 \mathrm{~g} / \mathrm{L})$. The sudden variation observed during the fermentation process corresponds to an increased consumption of the substrate due to prior adaptation of the yeast to the reducing sugars during the pre-fermentation phase. In parallel with the reduction of reducing sugars, there is a large increase in ethanol concentration. Indeed, the concentration of ethanol varies from $27.63 \mathrm{~g} / \mathrm{L}$ to $58.16 ; 104.3 ; 93.69 ; 73.95 ; 45.21 \mathrm{~g} / \mathrm{L}$, an increase of $30.53 ; 77 ; 66.06 ; 46.32$ and $17.58 \mathrm{~g} / \mathrm{L}$ respectively for yeasts $\mathrm{S} 1, \mathrm{~S} 2, \mathrm{~S} 3, \mathrm{~S} 4$ and wild-type strains. These analyzes show that the maximum concentration of ethanol $(104.3 \mathrm{~g} / \mathrm{L})$ is obtained with the yeast $\mathrm{S} 2$. Thus the strain $\mathrm{S} 2$ is revealed as the most efficient yeast in terms of alcohol production and consumption of reducing sugars. The abrupt increase in ethanol concentration during the first 48 hours of fermentation would be due to a prior adaptation of these yeasts during the pre-fermentation phase and their biofermentative potential to biodegrade the substrate to produce ethanol. The second phase is from the $2^{\text {nd }}$ to the $3^{\text {rd }}$ day. This phase is characterized by a total stabilization of the concentration of reducing sugars to an average value of $39.46 ; 1.25 ; 12.39 ; 16.7 ; 32.3 \mathrm{~g} / \mathrm{L}$ respectively for the yeasts S1, S2, S3, S4 and the wild strains. It remains constant until the end of the fermentation process. This indicates the cessation of the alcoholic fermentation reaction. This phenomenon is due to the different stresses experienced by the microorganisms involved in the fermentation (Novidzro et al., 2013). A similar phenomenon is observed in the kinetics of production of ethanol. Indeed, the concentration of ethanol remains constant at values of 58.16; 104.3; 93.69; 73.95 and 45.21 g/L respectively for yeast S1, S2, S3, S4 and wild-type strains. The third stage is from the $3^{\text {rd }}$ to the $4^{\text {th }}$ day and corresponds to a gradual decrease of the ethanol concentration up to $55.16 ; 100.58 ; 89.74 ; 70.16$; $41.27 \mathrm{~g} / \mathrm{L}$ is a decrease of $3 ; 3.32 ; 3.95 ; 3.79 ; 3.94 \mathrm{~g} / \mathrm{L}$ respectively for yeasts $\mathrm{S} 1, \mathrm{~S} 2, \mathrm{~S} 3$, S4 and wild-type strains. This decreasing tendency observed after 72 hours of fermentation could be explained by an overpressure of yeast activity due to the high concentration of ethanol and the depletion of reducing sugars (Cai et Nip, 1990) or the assimilation ethanol as an energy source (Zayed et Foley, 1987).

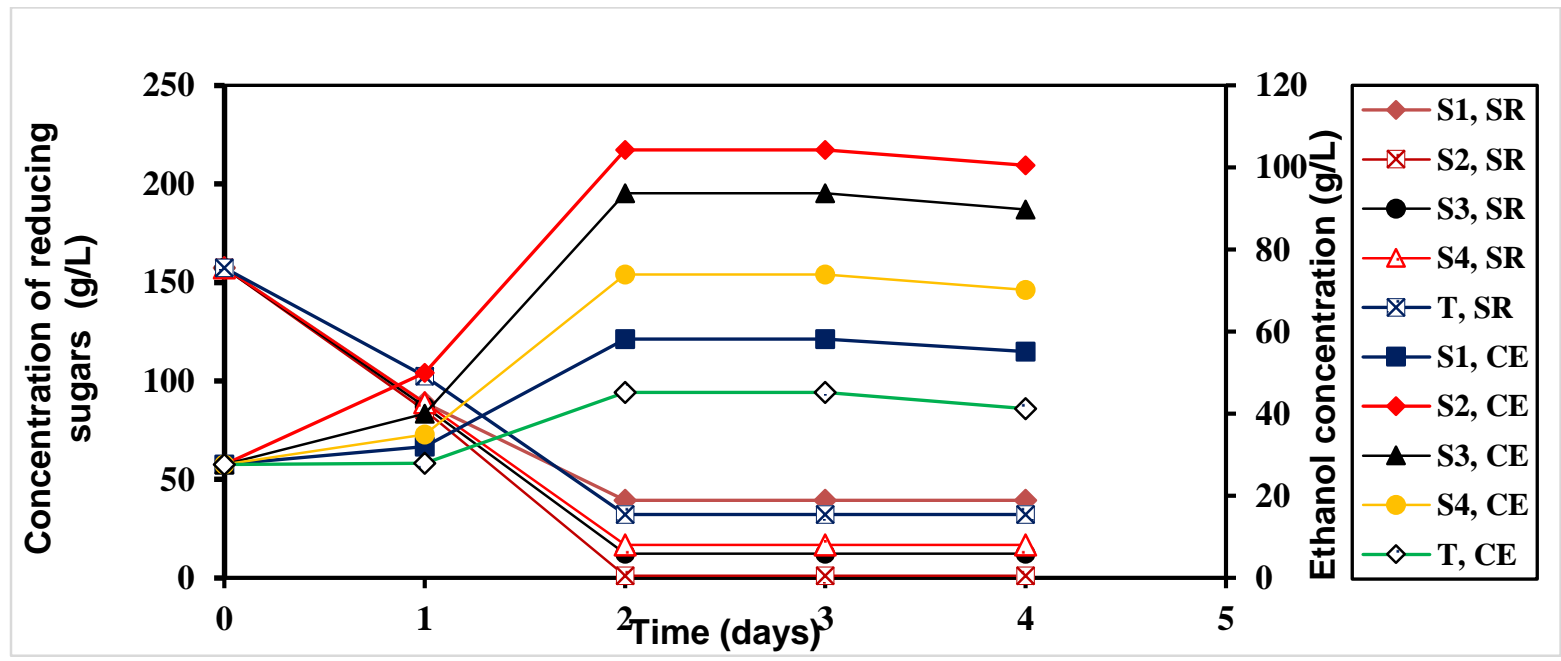

Figure 1: Variation of the concentration of reducing sugars $(\mathrm{g} / \mathrm{L})$ and ethanol $(\mathrm{g} / \mathrm{L})$ as a function of time (days) 


\begin{tabular}{|l|l|}
\hline S1 : Bakery yeast & \\
\hline S2 :Saccharomyces cerevisiae var. bayanus & T:Witness \\
\hline S3 : Saccharomyces cerevisiaeSafale K-97 & SR :Concentration of reducing sugars \\
\hline S4 :Saccharomyces cerevisiae Saflager W-34/70 & CE :Ethanol concentration \\
\hline
\end{tabular}

Evolution of cell biomass and dry extract as a function of the fermentation time according to the four strains of Saccharomyces cerevisiae

The results of the evolution of the cell biomass and of the dry extract as a function of the duration of fermentation are shown in figure 2. From the analysis of this figure, it appears that the kinetics of the cellular growth takes place in three phases. The first phase is from the $1^{\text {st }}$ to the $2^{\text {nd }}$ day and corresponds to a sudden decrease in the soluble dry matter of the reaction medium by the yeasts S1; S2; S3; S4 and wild strains. In fact, the content of soluble solids goes from $14{ }^{\circ}$ Brix to $5 ; 5.2 ; 5 ; 5.4$ and $7{ }^{\circ}$ Brix is a decrease of 8.8; 8.8; 8.8; 8.6; $7{ }^{\circ}$ Brix respectively for the yeasts $\mathrm{S} 1$; S2; S3; S4 and wild strains. The highest consumption of reducing sugars was recorded with S1 yeasts; S2 and S3. This sudden variation observed during the fermentation process corresponds to an increased consumption of fermentable sugars due to prior adaptation of the yeast to the reducing sugars during the pre-fermentation phase. The kinetic profile of the soluble solids is similar to that of reducing sugars. Along with the decrease in soluble solids, there is a large increase in cell biomass after 48 hours of fermentation: this is the exponential phase of cell growth. Indeed, the cellular biomass goes from $10 \mathrm{dg} / \mathrm{L}$ to $50 ; 40 ; 40 ; 40 ; 30 \mathrm{dg} / \mathrm{L}$ is an increase of $40 ; 30 ; 30 ; 30$ and 20 dg/L respectively for the yeasts S1; S2; S3; S4 and wild strains. The sudden increase in cell biomass would be due to a prior adaptation of yeast to reducing sugars during the pre-fermentation phase. The second phase is from the 2 nd to the 3 rd day. This phase shows a tendency towards stabilization of the soluble dry matter up to a value of $5^{\circ}$ Brix for the yeasts $\mathrm{S} 1, \mathrm{~S} 2$, $\mathrm{S} 3, \mathrm{~S} 4$ and $6^{\circ}$ Brix for the wild strains. In addition to the soluble dry matter, there is a total stabilization of the cellular biomass at $40 \mathrm{dg}$ for the yeasts S2, S3, S4 and $50 \mathrm{dg}$ for the yeast S1 then $30 \mathrm{dg}$ for the wild strains. This is the stationary phase of cell growth. This phenomenon is due to the high concentration of ethanol in the reaction medium (Cai et Nip, 1990). In addition to the soluble dry matter, there is a slight decrease in the cell biomass, which is explained by the presence in the reaction medium of $\mathrm{CO}_{2}$ and organic compounds (secondary metabolites) which inhibit the fermentative metabolism of Saccharomyces cerevisiae (Maiorella et al., 1983). This phenomenon is likely to induce the lethality of the microbial cells.

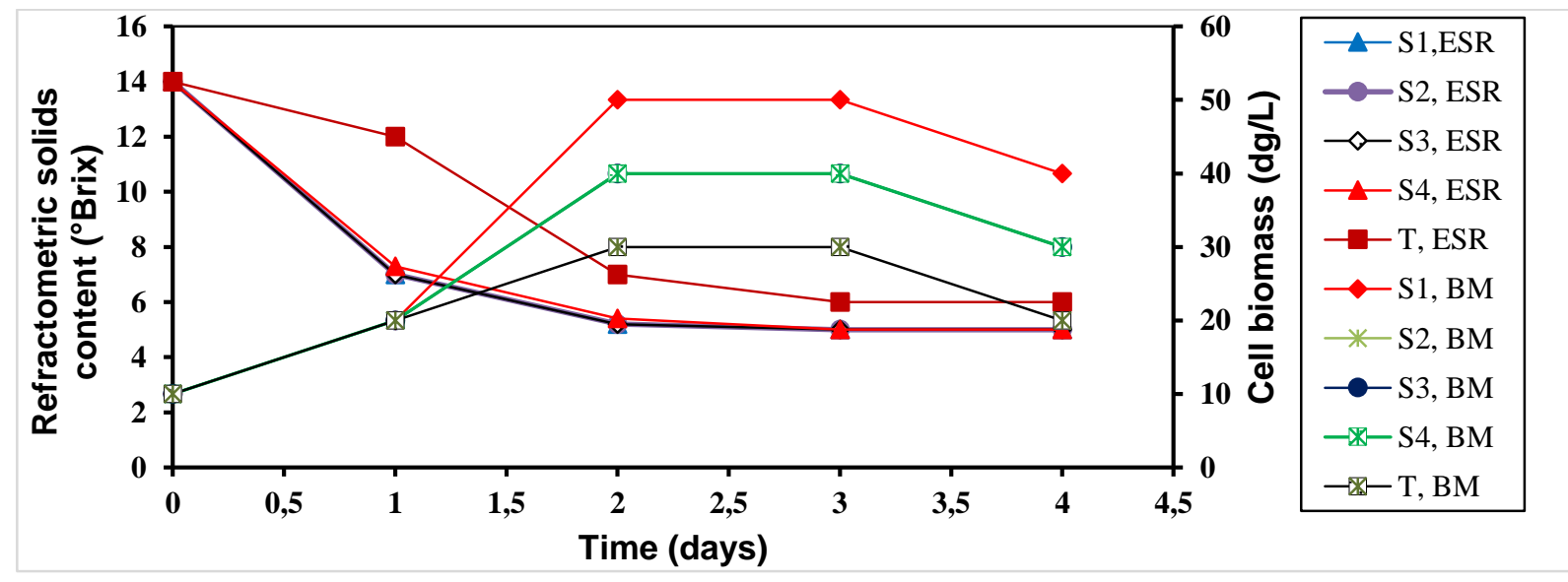

Figure 2: Variation of cellular biomass $(\mathrm{dg} / \mathrm{L})$ and soluble dry matter $\left({ }^{\circ}\right.$ Brix) as a function of time (days)

\begin{tabular}{|l|l|}
\hline S1 : bakery yeast & \\
\hline S2 $:$ saccharomyces cerevisiae var. Bayanus & T :Witness \\
\hline S3 : saccharomyces cerevisiaesafale $\mathrm{k}-97$ & ESR : Refractometric solids content \\
\hline S4 : saccharomyces cerevisiaesaflager $\mathrm{w}-34 / 70$ & BM :Cell biomass \\
\hline
\end{tabular}

Evolution of the pH and acidity according to the fermentation duration according to the four strains of Saccharomyces cerevisiae

The results of the evolution of the $\mathrm{pH}$ and the acidity as a function of the duration of fermentation are indicated in figure 3. It is apparent from the analysis of this figure that the $\mathrm{pH}$ slightly increases the first 24 hours of fermentation. Indeed, the $\mathrm{pH}$ goes from 4.32 to an average value of 4.41 , an increase of 0.09 . The slight increase in $\mathrm{pH}$ can be 
explained by the production of ethanol which modifies the dissociation constants of the constituents and in particular the organic acids (Akin, 2008). From the $1^{\text {st }}$ to the $2^{\text {nd }}$ day, the $\mathrm{pH}$ dropped considerably to reach values of $3.81 ; 3.95$; $3.76 ; 3.84$ and 3.75 respectively for the yeasts S1, S2, S3, S4 and the wild strains. Then, it remains practically constant until the end of the alcoholic fermentation process. According to Akin (2008), the no less considerable decrease in $\mathrm{pH}$ at the second day of fermentation is linked to the consumption of nitrogen sources. In general, the $\mathrm{pH}$ dropped from the first to the fourth day of fermentation. In addition, there was a slight decrease in acidity on the first day of the fermentation process which rose from $0.58 \%$ to $0.45 \%$ or a decrease of $0.13 \%$. Then it oscillates on average from 0.45 to $0.64 \%$ on the $4^{\text {th }}$ day of fermentation. It should be noted that the curve is rising from the third to the fourth day, thus reflecting an increase in acidity. Indeed, the increase in the acidity is a consequence of the decrease in $\mathrm{pH}$ and results from the production in the reaction medium of organic acids such as lactic acid, acetic acid and succinic acid (Bortolini et al., 2001). There is also citramalic acid, dimethylglyceric acid which is present in a small proportion (Akin, 2008). The increase in acidity could also be due to the formation of carbon dioxide in the reaction medium. Indeed, the carbon dioxide $\left(\mathrm{CO}_{2}\right)$ can be dissolved in the reaction medium in the form of carbonic acid $\left(\mathrm{H}_{2} \mathrm{O}, \mathrm{CO}_{2}\right)$, which is dissociated into hydrocarbon ions $\left(\mathrm{HCO}^{3-}\right)$, carbonate $\left(\mathrm{CO}_{3}{ }^{2-}\right)$ and hydrogen ion $\left(\mathrm{H}^{+}\right)($Garcia-Gonzalez et al., 2007). It is also verified that during the fermentation process the $\mathrm{pH}$ band (3.89-4.57) is sufficient enough to allow rapid alcoholic fermentation and inhibition of undesirable bacteria. Similar behaviors of $\mathrm{pH}$ and acidity were observed during the fermentation process by Bortolini et al. (2001), Andrate et al. (2003), Torres Neto et al. (2006). It is important to note that the variation in acidity during fermentation has a great influence on the stability and color of fermented beverages (Rizzon et al., 1994).
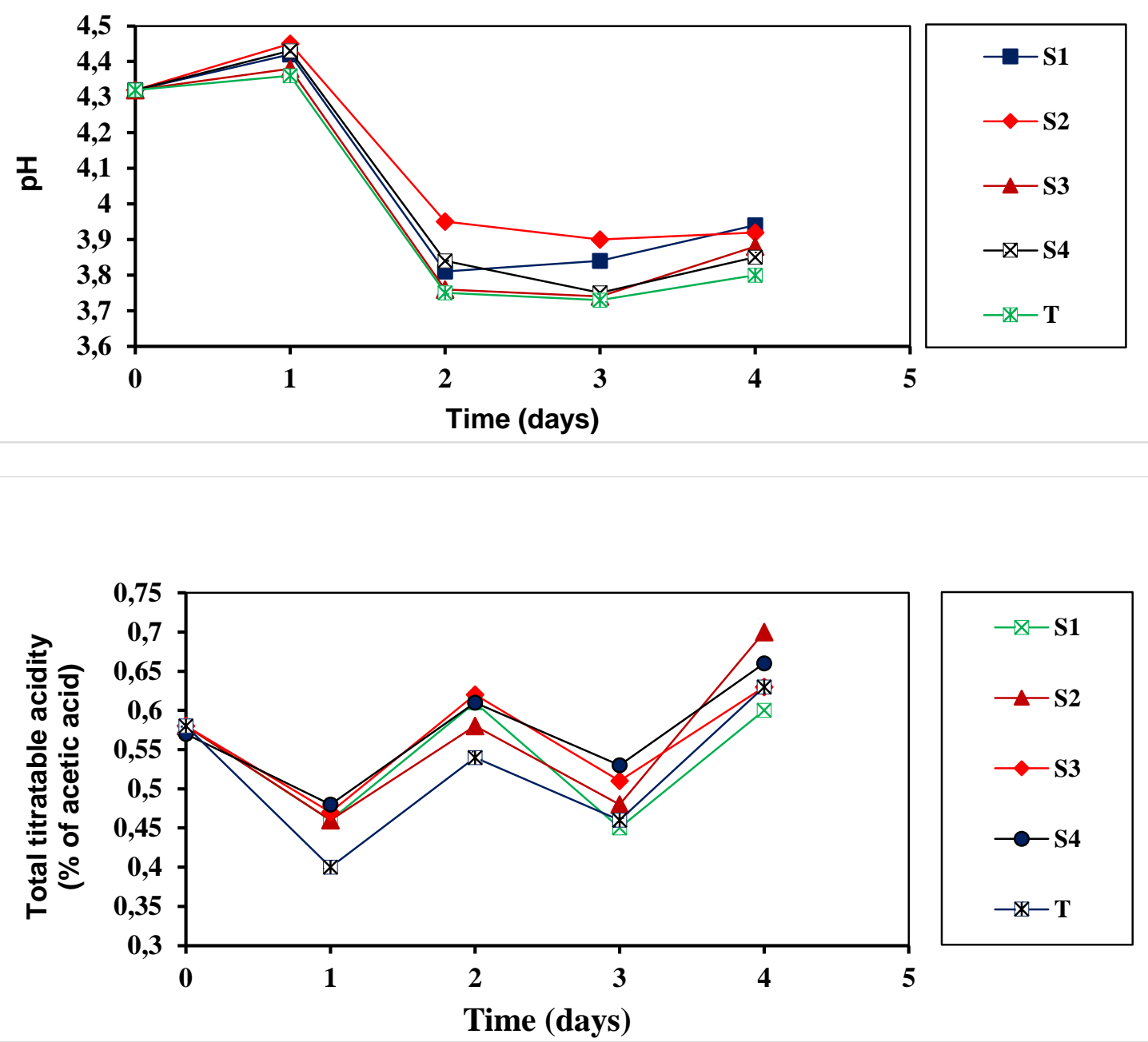

$-\otimes-S 1$
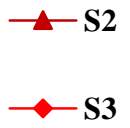

$-\mathrm{S} 4$

$-\mathbb{T}$ 
Figure 3: Variation in $\mathrm{pH}$ and acidity versus time (days)

S1 :Bakery yeast

S2 : Saccharomyces cerevisiae var. bayanus

S3 : Saccharomyces cerevisiae Safale K-97

S4 : Saccharomyces cerevisiae Saflager W-34/70

Evolution of the protein concentration as a function of the fermentation time according to the four strains of Saccharomyces cerevisiae

The results of the evolution of the concentration of proteins as a function of the duration of fermentation are shown in figure 4. It follows from the analysis of this figure that protein consumption is progressive until the end of the fermentation process alcoholic. Indeed, the protein content ranged from $12.80 \mathrm{~g} / \mathrm{L}$ to $3.99 ; 6.34 ; 3.78 ; 4.75$ and 6.80 $\mathrm{g} / \mathrm{L}$, a decrease of $8.81 ; 6.46 ; 9.02 ; 8.05$ and $6 \mathrm{~g} / \mathrm{L}$ respectively for yeast $\mathrm{S} 1, \mathrm{~S} 2, \mathrm{~S} 3$, S4 and wild-type strains. From the foregoing, it appears that yeasts have a strong ability to assimilate the proteins essential for their growth. According to Akin (2008), the variation in protein content during alcoholic fermentation is explained by the increased protein consumption by yeast as a nitrogen source.
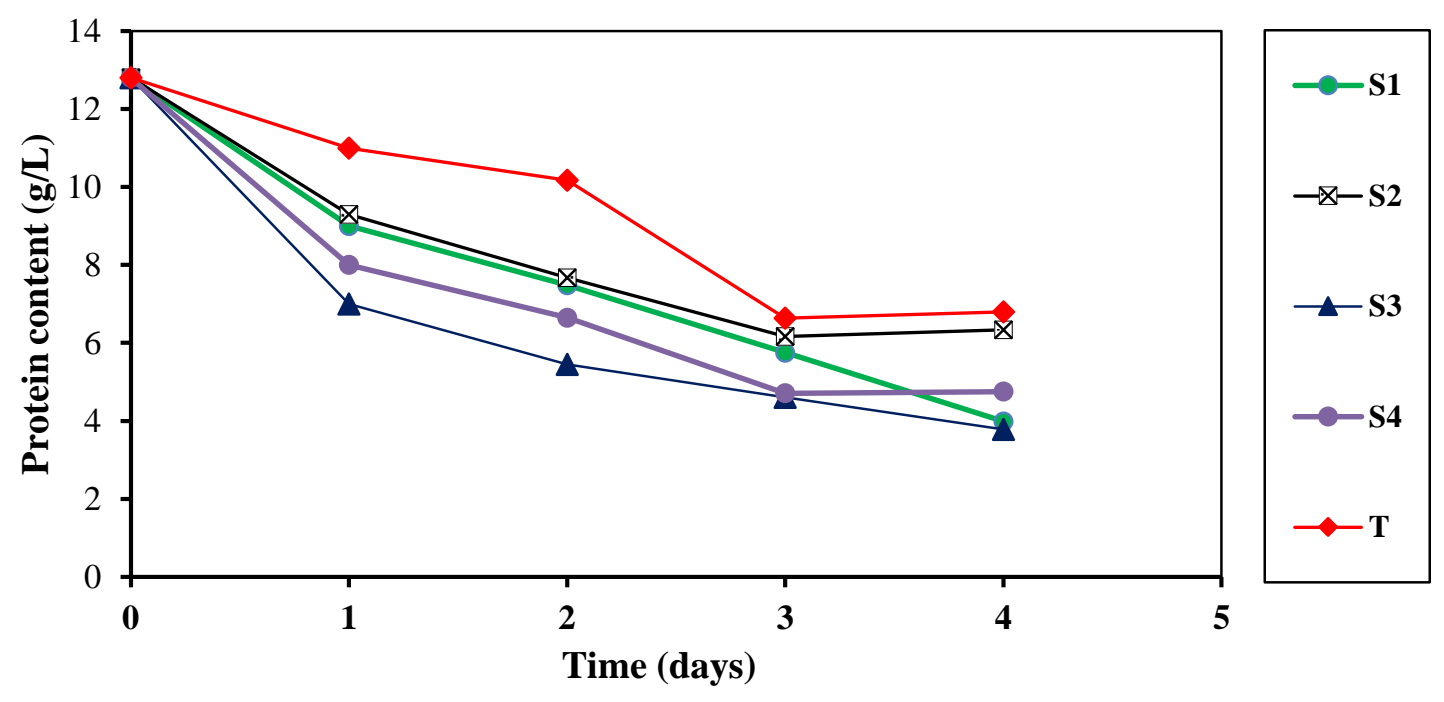

Figure 4: Variation in protein concentration (g/L) versus time (days)

\begin{tabular}{|l|l|}
\hline S1 : Bakery yeast & \\
\hline S2 : Saccharomyces cerevisiae var. bayanus & S4 : Saccharomyces cerevisiae Saflager W-34/70 \\
\hline S3 : Saccharomyces cerevisiae Safale K-97 & T :Witness \\
\hline
\end{tabular}

Values of kinetic parameters calculated to evaluate the performance of the four strains of Saccharomyces cerevisiae

Table 2: Kinetic parameters calculated to evaluate the performance of yeasts in the production of ethanol.

\begin{tabular}{|l|c|c|c|c|c|}
\hline \multirow{2}{*}{ Paramètres } & \multicolumn{5}{|c|}{ Levures } \\
\cline { 2 - 6 } & $\mathbf{S}_{\mathbf{1}}$ & $\mathbf{S}_{\mathbf{2}}$ & $\mathbf{S}_{\mathbf{3}}$ & $\mathbf{S}_{\mathbf{4}}$ & $\mathbf{T}$ \\
\hline $\mathrm{Al}(\%)$ & $74,946 \pm 0,511 \mathrm{a}$ & $99,206 \pm 0,301 \mathrm{~b}$ & $92,133 \pm 0,011 \mathrm{c}$ & $89,524 \pm 0,670 \mathrm{~d}$ & $79,492 \pm 0,512 \mathrm{e}$ \\
\hline$\mu_{\mathrm{s}}\left(\% \cdot \mathrm{h}^{-1}\right)$ & $1,561 \pm 0,551 \mathrm{a}$ & $2,067 \pm 0,333 \mathrm{~b}$ & $1,919 \pm 0,015 \mathrm{~b}$ & $1,865 \pm 0,676 \mathrm{~b}$ & $1,656 \pm 0,501 \mathrm{a}$ \\
\hline$\mu_{\mathrm{x}}\left(\mathrm{h}^{-1}\right)$ & $0,034 \pm 0,765 \mathrm{a}$ & $0,029 \pm 0,889 \mathrm{a}$ & $0,029 \pm 0,500 \mathrm{a}$ & $0,029 \pm 0,700 \mathrm{a}$ & $0,023 \pm 0,900 \mathrm{~b}$ \\
\hline$\mu_{\mathrm{p}}\left(\mathrm{g} \cdot \mathrm{L}^{-1} \cdot \mathrm{h}^{-1}\right)$ & $0,636 \pm 2,315 \mathrm{a}$ & $1,604 \pm 1,545 \mathrm{~b}$ & $1,376 \pm 3,168 \mathrm{c}$ & $0,956 \pm 2,755 \mathrm{~d}$ & $0,366 \pm 1,899 \mathrm{e}$ \\
\hline $\mathrm{Yx} / \mathrm{s}\left(\mathrm{g} \cdot \mathrm{g}^{-1}\right)$ & $0,034 \pm 2,375 \mathrm{a}$ & $0,019 \pm 2,913 \mathrm{~b}$ & $0,021 \pm 2,653 \mathrm{c}$ & $0,021 \pm 2,621 \mathrm{c}$ & $0,016 \pm 2,143 \mathrm{c}, \mathrm{a}$ \\
\hline $\mathrm{Yp} / \mathrm{s}\left(\mathrm{g} \cdot \mathrm{g}^{-1}\right)$ & $0,259 \pm 0,263 \mathrm{a}$ & $0,491 \pm 0,123 \mathrm{~b}$ & $0,455 \pm 0,123 \mathrm{~b}$ & $0,329 \pm 0,243 \mathrm{c}$ & $0,140 \pm 0,311 \mathrm{~d}$ \\
\hline$\eta(\%)$ & $50,615 \pm 0,213 \mathrm{a}$ & $96,025 \pm 0,135 \mathrm{~b}$ & $89,088 \pm 0,132 \mathrm{c}$ & $64,379 \pm 0,235 \mathrm{~d}$ & $27,479 \pm 0,373 \mathrm{e}$ \\
\hline
\end{tabular}


Values with the same letter on the same line are not significantly different ( $\mathrm{p}<5 \%$ ) from Turkey's multiple comparison tests.

\begin{tabular}{|l|l|}
\hline $\mathbf{S 1}:$ Bakery yeast & $\mathbf{S 3}:$ Saccharomyces cerevisiae Safale K-97 \\
\hline $\mathbf{S 2}:$ Saccharomyces cerevisiae var. bayanus & $\mathbf{S 4}:$ Saccharomyces cerevisiae Saflager W-34/70 \\
\hline $\mathbf{\eta}:$ Efficiency & $\boldsymbol{\mu}_{\mathbf{P}}:$ Total hourly productivity \\
\hline $\mathbf{Y}_{\mathbf{P} / \mathbf{s}: \text { Ethanol yield }}$ : & $\mathbf{Y x} / \mathbf{s}:$ Substrate conversion factor to cell biomass \\
\hline $\boldsymbol{A l}:$ Limit attenuation & $\boldsymbol{\mu}_{\mathbf{s}}:$ specific rate of sugar consumption \\
\hline
\end{tabular}

The analysis in this table shows that yeast S2 has the highest conversion efficiency of substrnate to ethanol (96.025 $\%)$, the highest hourly productivity $\left(1.604 \mathrm{~g} . \mathrm{L}^{-1} \cdot \mathrm{h}^{-1}\right)$, the smallest factor substrate conversion to biomass $\left(0.019 \mathrm{~g} . \mathrm{g}^{-1}\right)$, the highest yield of ethanol $\left(0.491 \mathrm{~g}^{-\mathrm{g}^{-1}}\right)$, the highest rate of substrate consumption $\left(2.067 \%\right.$. $\left.\mathrm{h}^{-1}\right)$. Thus the yeast $\mathrm{S} 2$ is revealed as the most successful strain. In fact yeast $S_{2}$ has a high tolerance to alcohol and has the phenotype "Killer", which allows it to have the greatest efficiency of conversion of the substrate ethanol and the best yield of ethanol. $S_{3}$ yeast also showed some interesting results. After the $S_{2}$ yeast, the $S 3$ strain exhibited the highest conversion efficiency of the substrate to ethanol $(89.088 \%)$, the highest hourly total productivity $\left(1.376 \mathrm{~g} . \mathrm{L}^{-1} \cdot \mathrm{h}^{-1}\right)$, the highest yield of

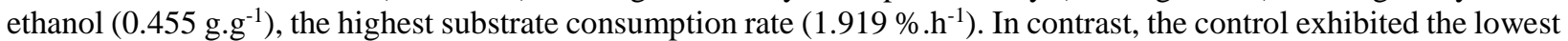
conversion efficiency of the substrate to ethanol $(27.479 \%)$, the lowest hourly productivity $\left(0.366 \mathrm{~g} . \mathrm{L}^{-1} \cdot \mathrm{h}^{-1}\right)$, the smallest substrate conversion factor to biomass (0.016 g.g-1), and the lowest yield of ethanol $\left(0.140 \mathrm{~g} . \mathrm{g}^{-1}\right)$.

The selected yeast $S_{1}$, for its part, proves to be the least effective of the four strains tested with a substrate conversion efficiency of $50.615 \%$ ethanol and an ethanol yield of $0.259 \mathrm{~g} . \mathrm{g}^{-1}$. But it is more effective in comparison with wild strains. In fact, the selected yeast S1 is a baker's yeast used in bread making. It allows resistance to alcohol. Thus the strains tested in the kinetics of alcoholic fermentation can be classified according to their performance as follows: S2> S3> S4> S1> T. The values obtained in this study are similar to those obtained by Pacheco et al. (2009), which found an effectiveness of 85.30 to $98.52 \%$, a $44.80 \%$ to $96.50 \%$ limit attenuation; a total hourly productivity of 3.30 to $6.31 \mathrm{~g} . \mathrm{L}^{-1} \cdot \mathrm{h}^{-1}$ and an ethanol concentration ranging from 19.82 to $37.83 \mathrm{~g} . \mathrm{L}^{-1}$ when studying the alcoholic fermentation of apple bagasse of cashew nuts in Brazil.

\section{Conclusion}

The yeast Saccharomyces cerevisiae var. bayanus had the highest concentration of ethanol with better ethanol yield and low substrate conversion to biomass. In addition, the calculated kinetic parameters showed that the best yields are obtained with the yeast Saccharomyces cerevisiae var. bayanus. Thus, it differs from other yeast strains by its high fermentative power. As a result, it can be used as a high performing strain for the purpose of intensive production of ethyl alcohol from cashew apple juice. 


\section{Reference}

1. Adou, M., Tetchi, F.A., Gbane, M., Niaba, P.V.K. and Amani N.G. (2011): Minerals Composition of the Cashew Apple Juice (Anacardium occidentale L.) of Yamoussoukro, Cote d'Ivoire. Pakistan Journal of Nutrition, 10: 1109-1114.

2. Adou, M., Kouassi, D.A., Tetchi, F.A. and Amani N.G. (2012a): Phenolic profile of Cashew (Anacardium Ocidentale L.) of Yamoussoukro and Korhogo, Cote d'Ivoire. Journal of Applied Biosciences, 49: 3331-3338.

3. Adou, M., Tetchi, F.A., Gbané, M., Kouassi, K.N. and Amani N.G. (2012b): Physico-chemical characterization of cashew apple juice (Anacardium occidentale, L.) from Yamoussoukro, Côte d'ivoire. Innovative Romanian Food Biotecthnology, 11: 32-43.

4. Akin, M.H. (2008): Evolution du pH pendant la fermentation alcoolique de moûts de raisins: modélisation et interprétation métabolique. Thèse de Doctorat ; Institut National Polytechnique de Toulouse. 136p.

5. Akomagni, A.L. (2017): Etude diagnostique du fonctionnement du marché de l'anacarde et perspectives sur les politiques nationales de développement de la filière au Bénin. Rapport final, DEDRAS-ONG, Bénin, 100p.

6. Andrade, J.S., Pantoja, L. and Maeda, R.N. (2003): Melhoria do rendimento e do processo de obtenção da bebida alcoólica de pupunha (Bactris gasipaes Kunth). Ciência e Tecnologia de Alimentos. Campinas, 23: 34-38.

7. Bando, P.M. and Silva, C.A.B. (2001): Sistema agroindustrial de frutas na zona da mata mineira: agentes, organizações e ambiente institucional. Revista Ceres, 311-331.

8. Bortolini, F., Sant'anna, E. S. and Torres, R.C. (2001): Comportamento das fermentações alcoólica e acética de sucos de kiwi (Actinidia deliciosa); composição dos mostos e métodos de fermentação acética. Ciência Tecnologia Alimentos, Campinas, 21: 236-243.

9. Cai, T. and Nip, W.K. (1990): Biochemical changes in the development of alcoholic fermented products from Taro (Colocasia esculenta), Trop. Sci., 30: 379-390.

10. Boulal, A., Benbrahim, Z., Benali, B.and Ladjel, S. (2013): Etude comparative de rendement de la production d'éthanol de deux variétés de dattes communes de faible valeur commerciale (Tinaceur et Aghmou) de Sud Ouest de l'Algérie. Revue des Energies Renouvelables, 16: 539-550.

11. Cavarlho, J.M., Maia, G.A., Figueiredo, R.W., Brito, E.S. and Rordrigues, S. (2006): Development of a blended beverage consisting of coconut water and cashew apple juice containing caffeine. International Journal Food Science Technology, 42: 1195-1200.

12. Cavalcante, A.A.M., Rubensam, G., Picada, J.N., Silva, E.G., Moreira, J.C.F.and Henriques J.A.P. (2003): Mutagenicity, antioxidant potential and antimutagenic activity against hydrogen peroxide of cashew (Anacardium occidentale) apple juice and cajuina. Environ. Mol. Mutagenesis, 41: 360-369.

13. Dédéou, E.S.C.A., Dossou, J., Ahohuendo, B., Saïdou, A., Ahanchede, A. and Soumanou, M.M. (2015): Optimization of cashew (Anacardium occidentale L.) apple juice's clarification process by using cassava and rice starch. Journal of Applied Biosciences, 95: 8989-9002.

14. Demirbas, A.H. and Demirbas, I. (2007): Importance of rural bioenergy for developing countries. Energy Conversion Management, 48: 2386-2398.

15. Demirbas, A. (2008): Biofuels sources, biofuel policy, biofuel economy and global biofuel projections. Energy Conversion and Management, 49: 2106-2116.

16. Etéka, C.A. (2017): Etude diagnostique sur les contraintes et les opportunités à l'accès aux intrants dans les maillons de production et de transformation au Bénin. Rapport final, Bénin, 32p.

17. FAO (2018): Base des données de la FAO 2018. Food and Agriculture Organization (FAO), Rome, Italie, http:// faostat3.fao.org. Visité le 01 Octobre 2018 à $13 \mathrm{~h} 30 \mathrm{mn}$.

18. Gbohaïda, V., Mossi, I., Adjou, S.E., Agbangnan, P., Yèhouenou, B.B. and Sohounhloue, C.K.D. (2015): Morphological and physicochimical characterization of cashew apples from Benin for their use as Raw material in bioethanol production. International Journal of pharmaceutical Sciences Review and Research, 02: 7-11.

19. Gornall, A.G., Bardawill, C.J. and David, M.M. (1949): Détermination of serum proteins by means of the biureto reaction. Journal of Biological chemistry, 177: 751-766.

20. Holanda, J.S., Oliveira, A.J. and Ferreira, A.C. (1998): Enriquecimento protéico de pedúnculo de caju com emprego de leveduras, para alimentação animal. Pesquisa Agropecuária Brasileira, Brasília, 33: 787-792.

21. Kaidi, F. and Touzi, A. (2001): Production de bioalcool à partir des déchets de dattes. Review of renewable energy, 75-78.

22. Kouchadé, C.A., Kounouhewa, B. and Awokou, S.K. (2017): La récolte de vin palme: procédé et effets des conditions environnementales. Oilseeds \& fats Crops and Lipids, 24(5), D 505.

23. Kubo, I., Masuoka, N., Ha, T.J. and Tsujimoto K. (2006): Antioxidant activity of anacardic acids. Food Chemitry, 99: 555-562.

24. Lacroix E. (2003): Les anacardiers, les noix cajou et la filiere anacarde a bassilia et au Benin, Terra Systems, 47p. 
25. Maiorella, B.L., Blanch, H.W. and Wilke C.R. (1983): Byproduct inhibition effects on ethanolic fermentation by Saccharomyces cerevisiae. Biotechnol. Bioeng, 25: 103-121.

26. Massengo, V., Loumouamou, B.W., Diakabana, P. and Silou, T. (2014): Ethanol production fermentation of the pulpe of BOKO mango. International Journal of Chemical Science and Technology, 4: 71-77.

27. Nanjundaswamy, A.M., Radhakrishniah, S. and Patwardhan, M.V. (2001): Utilization of cashew apples for the development of processed products. Central Food Technological Research Institute Mysore-570013, Karnataka, India, 152-159.

28. Novidzro, K.M., Agbodan, K.A. and Koumaglo, K.H. (2013): Étude de la performance de quatre souches de saccharomyces cerevisiae au cours de la production d'éthanol à partir des moûts de sucrose enrichis. J. Soc. OuestAfr. Chim., 035, 1-7.

29. Ohler, J.G. (1967): Cashew. Department of Agricultural Research, Royal Tropical Institute, Amsterdam, 26p.

30. Pacheco T.F., 2010. Fermentação alcoólica com leveduras de característica floculantes em reator tipo torre com escoamento ascendente. Dissertação (Mestrado em Engenharia Química), Faculdade de Engenharia Química, Programa de Pós-Graduação em Engenharia Química, Universidade Federal de Uberlândia, Minas Gerais.

31. Parenté, L.D.G., Almeida, M.M., Silva L.J., Silva, C.G. and Alves, F.A. (2014): Kinetic production of alcoholic unfermented pineapple 'pearl' drink and characterization. Revista Verde de Agroecologia e Desenvolvimento Sustentável, 9: 230-247.

32. Reddy, V.L. and Reddy, O.V.S. (2007): Production of ethanol from Mango (Mangifera indica I) fruit juice fermentation. Research Journal of Microbiology, 2(10): 763-769.

33. Rizzon, L.A., Zanus, M.C. and Manfredini, S. (1994): Como elaborar vinho de qualidade na pequena propriedade, $3^{\mathrm{a} e d ., ~ B e n t o ~ G o n c ̧ a l v e s: ~ E M B R A P A-C N P U V, ~} 36$.

34. Silva M.E. (2006): Estudos cinéticos da fermentação alcoólica da produção de vinho e da fermentação acética de produção de vinagre de vinho de caju. Dissertação (Mestrado em Engenharia Química), Universidade Federal de Campina Grande, Campina Grande, 137p.

35. de Sousa, M., Mesquita, F.M.R., Freitas, M.M.M., dos Santos, J.C.S., Sa, T.N.M. and Pinto G.A.S. (2010): Fermentação alcoólica utilizando suco do pedúnculo de caju (anacardium occidentale L.), XVIII ${ }^{\text {e }}$ congrès brésilien de l'énergie chimique, 6960-6966.

36. Soyer, Y., Koca, N. and Karadeniz F. (2003): Organic acid profile of Turkish whites grapes and grapes juices. Journal of Food Composition and Analysis, 16: 629-636.

37. Stroppa, C.T., Alves, J.G.L.F., Figueiredo, A.L.F. and Castro, C.C. (2009): Parâmetros cinéticos de linhagens de levedura isoladas de alambiques mineiros. Ciência e Agrotecnologia, 33: 1978-1983.

38. Tandjiékpon, A.M. (2005): Caractérisation du système agroforestier à base d'anacardier (Anacardium occidentale Linnaeus) en zone de savane au Bénin. Diplôme d'Études Approfondies (DEA), Université d'Abomey-Calavi, Bénin, 122p.

39. Tokpa, C. and Adoho, E.H. (2006): Valorisation de la pomme cajou en alcool alimentaire par une technologie artisanale dans la région des collines. Rapport technique et financier, Centres de Recherches Agricoles du Centre Bénin de l'Institut National des Recherches Agricoles du Bénin (CRA-Centre/INRAB), Bénin, 20p.

40. Torres Neto, A.B., Silva, M.E, Silva, W.B., Swarnakar, R. and Silva, F.L.H. (2006): Cinética e caracterização físico-química do fermentadodo psudofruto do caju (Anarcadium occidentale L.). Química Nova, 29: 489-492.

41. Yabi I. (2018): Etude de l'agroforesterie à base de l'anacardier et des contraintes climatiques à son développement dans le Centre du Bénin. Thèse de Doctorat Unique. Faculté des Lettres, Arts et Sciences Humaines de l'Université d'Abomey-Calavi (FLASH/UAC), 235p.

42. Yu Z. (2004): Zhang H. Ethanol fermentation of acid-hydrolysed cellulosic pryolysate with Saccharomyces cerevisiae. Biores.Technol, 93, 199-204.

43. Zayed, G. and Foley J. (1987): The influence of the fermentation conditions on ethanol yields from sugar beet molasses and fodder beet juice using Sacchromyces cerevisiae strains, Irish J. Food Sci. Technol., 11: 119-133. 